\title{
Empire and the Ambiguities of Love
}

\author{
LINNELL SECOMB \\ GREENWICH UNIVERSITY
}

-INTRODUCTION

Wandering through a maze of fake-foliage covered trellises, the viewer chances upon groups of lovers that seem at once strangely familiar and disquietingly foreign. Yinka Shonibare's installation, Jardin d'Amour, commissioned by, and first exhibited at, the Musee du Quai Branly in Paris in 2007, reinterprets Jean-Honoré Fragonard's 1770s' rococo scenes of aristocratic love, revealing the colonial wealth that made possible such idyllic romanticism. The opulence of Fragonard's paintings remains but the satins and silks of the original breeches, gowns and bustles have been replaced by vibrant, patterned 'African' wax-print fabrics, clothing life-size headless mannequins. Otherness flamboyantly intervenes into European conventions of seduction and courtship, entwining love with fear, banality with exoticism, familiarity with alterity.

Referencing colonialism and foreshadowing the decapitations of the French Revolution that will soon follow these eighteenth-century scenes, Shonibare's work also disturbs the relation between love and colonialism. By inserting 'African' wax-print fabrics into European love scenes he at once evokes the 
colonialism that financed these games of pleasure and creates a hybrid image of love in which Africa is interleaved with Europe and/or Europe becomes Africanised. Shonibare's work raises questions of the relation between love and colonialism, asking: How has love been experienced and expressed in the colonial and postcolonial context? Has love been used as an instrument of empire or does it function as a mechanism for the overcoming of imperialism? And does the colonial experience of love enable a new perspective on the conventional formulations of love?

This article reflects on these questions using Shonibare's work as a provocation to reconsider the forms, uses and depictions of love in colonial and postcolonial contexts. While the literature on love and colonialism is small, there is already a clearly demarcated division between two positions in relation to colonial love. The first depicts love as a tool of empire, as a mechanism of control and exploitation, which justified and partially disguised the abuses of empire while also facilitating alliances and occupations that enabled colonial ambitions to be attained. The second, more utopian perspective, sees love as the basis for a resistance to the objectives of colonialism. Love of humanity as a whole, or of the particular Other, is envisaged as the motivation for a refusal of the violence that is colonial conquest. To contest and dismantle this dichotomy, the article draws on the work of various theorists, including Matt Matsuda, Elizabeth Povinelli, Chela Sandoval, Leela Gandhi and Jean-Luc Nancy, from a range of disciplines such as history, anthropology, literary theory and philosophy. It creates a 'conversation' between these theorists and Shonibare's installation that allows the theories to be sketched and a 'response' inspired by Jardin d'Amour to be proposed.

Shonibare's Jardin d'Amour challenges, I will suggest, the traditional bifurcation of love into imprisonment (for example, within the restrictions of coupledom) on the one hand, or freedom on the other. Contesting this dichotomised view, Shonibare's work suggests that love is an intrusion of the other into the self and of the self into the other that touches and exposes each so that the lovers are always necessarily transformed by the process of love. This is a violence but it is also the creation of new possibilities, trajectories and futures. Shonibare's frequent use of wax-print fabrics and headless mannequins is generally read as a critique of the economic inequalities and abuses of colonialism, and a warning about the on-going disparities 
in our present post-colonial era. The reviews of Jardin d'Amour continue this interpretation and ignore the centrality of love to the work. ${ }^{1}$ This obscures an important aspect of Shonibare's installation, which can be interpreted as a commentary on the functioning of love in colonial and postcolonial relations that contests the simplistic division of love into an expression of freedom or a subjugation of the self. Shonibare's work disrupts the dichotomous construction of love by revealing the violence and entwinements of love that simultaneously create bonds while also tearing apart fixed and established identities and commitments.

\section{-JARDIN D'AMOUR'S 'AFRICAN' WAX-PRINT FABRICS}

Fragonard's 'The Lover Crowned', 'Love Letters', 'The Meeting', 'The Pursuit': all take place in ornate, highly stylised rococo gardens dappled with sunlight, setting the scene for the romantic encounters between sumptuously dressed eighteenthcentury French patricians. In 'The Lover Crowned' a woman holds a wreath over a man's head as they play together at courtly love. Adorned with flowers and dressed lavishly in a golden, bustled, elaborately draped gown and lace neck-ruff she reflects affluence, privilege and indulgence. He is similarly ostentatiously attired in regal red tightly fitted knee length breeches and flowing red jacket and white neck-ruff. These depictions of pleasure gardens, romantic encounters and advantaged nobility form a series, Les progrès de l'amour, that Louis XV's mistress, Madam du Barry, commissioned from Jean-Honoré Fragonard, for her garden pavilion at Louveciennes. $^{2}$

Though Madam du Barry ultimately rejected the paintings and returned them to the artist, they were designed specifically for her pavilion. Two of the works were to flank the large glass door leading to the gardens and two were for the opposite wall, one for each side of a door leading into an inner room. ${ }^{3}$ Many theorists have attempted to create a narrative about love from the images suggesting, for example, that The Pursuit depicts the first encounter when the lover offers a rose to the startled beloved, The Meeting an arranged tryst, The Lover Crowned their marriage or sexual union, and The Letters the more mature stage of love that has become friendship. Mary D. Sherrif contests this imposed narrative, pointing out that the group title 'The Progress of Love' was attributed to the paintings at a later stage and that the figures in each painting are different, which undermines the assumption 
that this is a story of particular love. She argues instead that the works reflect themes of contrast and interplay between opposites such as nature and art, reality and illusion, original and representation. ${ }^{4}$

All the paintings depict figures set within ornate gardens and their intended positions around the doors leading into and away from the gardens would have created a connection with the outside while also positing the representation against the 'original' or 'real' garden. Within the paintings, too, artifice and naturalness are contrasted through the simultaneous overgrown wildness of the foliage and its structuring around urns, terraces, plinths and sculptures. In addition, the relation of real and illusory is evoked again by the similarities of the painted figures and the painted sculptures. Most significantly, in 'The Lover Crowned' the lover and beloved are depicted along with an artist who has artfully arranged and now sketches the scene, so that the process of representation and memorialisation are explicitly explored within the work. ${ }^{5}$

Most importantly, Sherrif argues that 'The Progress of Love' has no predetermined narrative but offers many possible interpretations and entry points. Sherrif compares Fragonard's works to a garden in which the gardener plans and creates some structure-through the placement of plantings, walkways, buildings and sculptures-but the visitor chooses where to enter the garden and how to meander through it. Similarly, 'the panels', Sherrif writes, 'both suggest a story and withhold a predetermined narrative order, thus engaging the audience in a lively exchange'.6

By the 1770s when these painting were created, France had already established a far-reaching colonial empire, which partly funded the extravagances of the French courts and nobility. Acadia, in northern Americas and Canada, was claimed as French in the early 1600s, facilitating the development of the fur trade. The French colonies in northern America developed as merchant colonies and stretched from Louisiana to the Great Lakes. In the 1620s, French colonialism expanded to include regions in the Caribbean and southern America. Here, plantations created and maintained through slavery augmented already considerable colonial wealth. During the same period the French established trading posts in Africa and in the 1660s penetrated into Asia and the Indian Ocean. ${ }^{7}$ Much of this colonial territory was lost to Britain during the wars of the late 1700s; nevertheless in the $1770 \mathrm{~s}$ 
colonialism facilitated a life of extravagance, pleasure and frivolity for the French nobility.

Yinka Shonibare references this colonial history when he reinterprets and recreates Fragonard's rococo paintings in his installation, Jardin d'Amour. Life-size, headless mannequins mimic the positions and gestures of Fragonard's patricians and their luxurious costumes are reproduced in minute detail with every bustle, button and buckle exquisitely recreated. The golden and red satins of the original, however, have been replaced with 'African' wax-print fabrics-the brightly coloured patterned materials derived from Indonesian batiks that have now come to epitomise Africanness.

The history of the 'African' wax-print fabric itself reveals the interconnectedness of cultures. Inspired originally by Indonesian batiks, these designs and techniques were emulated by the Dutch and manufactured in the Netherlands and Manchester before being sold to a West African market. ${ }^{8}$ The Dutch fabrics were originally intended for Indonesian consumption but they were inferior to the local product and did not sell there. Instead, the fabrics were diverted to West Africa and later the whole African continent.. Javanese batik is created by applying hot liquid wax to areas of undyed cloth. Once hardened, the wax protects the fabric from the dye in which it is submerged. If the wax cracks the dye can affect unintended areas, creating the characteristic irregular veined pattern, though the aim is to avoid this effect. The Dutch imitation batik does not use this technique; instead the fabrics are printed on rollers using designs derived from original batiks. ${ }^{10}$ The 'African' fabric is not, therefore, technically 'wax-print' though it emulates the wax-print patterns and effects.

These fabrics conflate and confuse any notion of authenticity and cultural specificity, pointing to what Homi Bhabha has named 'culture's in between' and suggesting that cultures are always and from the beginning mixtures of different cultures. ${ }^{11}$ Shonibare, through his use of these fabrics, unsettles conventional readings of Fragonard's work and reveals the colonial history that underlies them. This insertion not simply of an 'African' fabric but of a hybrid (Indonesian-DutchAfrican) material into European love scenes radically challenges the separation of cultures, revealing how cultures are entwined with and dependent on one another. 
The fabrics, thus, create a paradox that unsettles the romantic idyll of the original artwords.

Shonibare's differing repetition of Fragonard is realised through a metonymic displacement that discloses the hybridity already operating at the heart of French aristocratic love This disorienting mimicry, an almost the same that is nonetheless different, introduces an ambivalence that disrupts the authority and security of the Western imagery, which had disguised or disavowed its interconnection with and reliance on, or rather its subjugation of, the Other. For Bhabha, mimicry 'rearticulates presence in terms of its "otherness", that which it disavows'.12 Shonibare's mimicry brings to consciousness the disavowed violent origins of colonial indulgence while also replicating otherwise the ambiguities of colonial and postcolonial relations.

This disruption is accentuated by the decapitated mannequins that forewarn of the Revolutionary moment that follows less than twenty years after Fragonard's paintings, which, ironically, was also to take the head of Madame du Barry who had commissioned Fragonard's works. These aristocratic games of love, the palace gardens, the scenes of luxurious play and privileged indulgences were all destined to be wiped away by the demands of universal rights and citizenship.

The anxiety provoked is further intensified by a comparison with the present moment. The inequalities of the past created by colonial conquest and the slave trade may have been transformed but continue in other guises, with the privileged West continuing to benefit from the exploitation of Africa, Asia and the developing world. The wax-print fabrics Shonibare selects for the installation depict presentday 'luxury-goods logos, car designs, dollar bills and coins' highlighting the wealth and privilege evident in the original Fragonards while also creating a connection with the current situation. ${ }^{13}$ Yinka Shonibare conceives this work as a metaphor for the present in which resistance in the form of terrorism and social and political upheaval herald a renewed challenge to the inequality of contemporary global relations. 'We have a situation now where there is a global underclass that is actually fighting the privileged, i.e. Westerners. It's a terrible situation: it's prerevolutionary', Shonibare argues and he sees his work as a warning, 'that you can have all this luxury, but you will have it at the expense of your head.'14 
Finally, and most crucially for this article, Shonibare's work also alludes to the place of love in the colonial encounter. Shonibare's unfaithful citation of Fragonard's depiction of patrician love troubles reinterprets these Western narratives of love. The conventions and protocols of European seduction and flirtation, so evident in the original works, are now transported into the space of colonialism, provoking reflection on the role of love in colonial conquest. Shonibare's work is not only pointing to the role of empire in financing the indulgences of aristocratic life, and is not simply a warning that this indulgence comes at a cost, but also places love at the centre of these past and present situations. Shonibare's work suggests that colonialism is not enacted through violence alone but may also be enabled through the strategies of love.

-EMPIRE OF LOVE

While Jardin d'Amour reinterprets a French eighteenth-century work by introducing 'African' fabric, this commentary on colonialism should not be confined either to the eighteenth century or to France in Africa. Indeed, Shonibare's wax-print materials, while now associated with Africanness, are derived from Indonesia and were transformed and globalised by the Dutch and British. Moreover, until the early nineteenth century French activity in Africa was relatively contained and it was only in 1830 that France invaded Algeria and then began the gradual process of claiming territory throughout northwestern and central Africa that continued into the early twentieth century. Shonibare's intervention into Fragonard's representation of courtship and love should not therefore be read in relation to the particularities of eighteenth-century French colonial strategies in Africa but more broadly regarding the role of love in the colonial encounter globally.

A small number of theorists have analysed colonial love with a focus on a range of contexts-the French in the Pacific, the British in Australia and in India-and it is the observations about these situations that will be articulated with Shonibare's work.

Historian Matt Matsuda argues, for example, that nineteenth-century French imperialism was facilitated by discourses that depicted conquest as a process that offered civilising and paternal love for the original inhabitants of conquered territories, and encouraged alliances between settlers and the original inhabitants 
as a means of consolidating occupation. Matsuda cites the instructions given to Pacific administrators to spread civilisation through out their regions and, especially, to encourage devotion to France by 'making the natives love France'. ${ }^{15} \mathrm{He}$ remarks also on the perception of a difference in the character of French and British imperialism: French imperialists, he explains, believed that, unlike the English who exploited the colonised, French colonialism was wrought through a genuine affinity between coloniser and colonised. This mythology of fellow-feeling far from undermining conquest facilitated invasion and occupation-love was not a resistant discourse but instead a part of the mechanism of colonial power. As Matsuda explains: 'Where French empire extended under royal and then republican rule in the nineteenth century, perhaps the most compelling of civilizing narratives was that which reconfigured possession into passion, and drew the legacies of sentimentalism into the age of the nation: imperialism registered in language of love.'16

The nineteenth-century novels by naval officer and writer Pierre Loti attest to, and promulgate, such tales of French Pacific intimacy and affinity. His The Marriage of Loti (1880) depicts a liaison between the character Loti and the Polynesian princess Rarahu that is approved and endorsed by the Tahitian ruler Queen Pomare. Fusing private passions with imperial strategy the novel communicates 'imperialism as a kind of family romance'.17 Obscuring the harsher aspects of colonial rulewarfare, unequal treaties, sexual exploitation and deadly disease-Loti narrates the colonial encounter as charming by depicting it as an amorous, exotic, beneficent and respectable encounter. Loti's novels, which were popular and influential, though not overtly political, inscribe colonial ambitions as sentimental love stories and provide a distraction from the other strategies of empire.

Tellingly, Loti's attempts to write about the violence of French territorial expansion met with disapproval and censure. His account in Le Figaro of a French attack on and massacre of Chinese and Tonkinese in the Red River delta resulted in his recall from Southeast Asia. Recognising that Empire was always and only to be depicted as charming romance and not as violent and murderous assault, Loti wrote sarcastically: 'the people cry horror because it is the first time that the realities of war-and an exotic war-are put before their eyes. That's the whole problem; it is true, I should have soothed and calmed their nerves'.18 
For Matsuda, French imperial strategy in the Pacific inevitably evoked the concept of love though it was adapted to suit the particularities of each context. In Tahiti, alliances between Tahitian women and outsiders enabled the creation of social and political prestige, but this system of using women for political ends was not evident in New Caledonia. ${ }^{19}$ As a result, imperial strategy in New Caledonia concentrated on the development of family love by encouraging the wives and children of French convicts imprisoned in New Caledonia to join their husbands and fathers upon their release, and to establish farms and small businesses in the colony. Female prisoners were also sent to the colonies with the hope that they would marry male prisoners and settle in New Caledonia. ${ }^{20}$

What emerges from this history of French Pacific colonial conquest is the entangling of romance, power and imperial imperatives that together bring into being the Pacific Empire of Love. The policies that promoted family formation and erotic alliances not only facilitated assimilation, settlement and territorial expansion but also disguised the massacres and wars that characterised this period. The conquest of the Pacific did involve strategies of seduction but it also involved armed invasion that was resisted by both the Polynesians of Tahiti and the Kanaks of New Caledonia. But these wars have been obscured by an official representation that prefers to clothe conquest in the language of passion, sentimentalism and love. This Empire of Love operates, then, on at least two different levels: as a means of seductive coercion and as a technology of concealment.

\section{- JARDIN D'AMOUR'S COLONIAL SEDUCTIONS}

Shonibare's installation reveals not just the colonial exploitations that financed aristocratic life but also foregrounds the strategies of love employed to facilitate colonial conquest. His work reproduces the romanticised fantasies of love that Fragonard invokes, but this is undercut by the decapitated mannequins. Shonibare has used this trope repeatedly throughout his oeuvre to similar effect. Yet here it seems to specifically question the validity of the fantasy of romantic love. The headless figures connote not just the French Revolution to come and the violence of colonial conquest but also the risks inherent in the use of love as a strategy of imperialism. If, as Matsuda contends, colonialism is facilitated through discourses of fraternal, familial and erotic love, then Shonibare's work supports and elaborates 
this insight. The discourse of colonial love may promote the ambitions of empire but it does so at a cost: the loss of the empire's head.

of course the guillotine and other forms of physical beheading are not the only way to lose one's head. In English idiom the expression 'to lose your head' suggests the loss of emotional control and thereby the loss of the ability to make reasoned judgments. This may occur through anger, excitement or infatuation. Love is not uncommonly associated with such a form of unreasoned madness: one loses one's head in rashly pursuing or engaging in a liaison fraught with danger.

Shonibare has made clear that his headless mannequins gesture not only to the cost of past aristocratic indulgences but also to current global inequalities. In addition, given the thematics of love and colonisation that this work elaborates, there is a further implication: that the strategies of colonial love are riddled with emotional excess and unreason. To attempt to disguise conquest as love, and to obtain compliance through love, may appear to be reasoned tactics, yet the realities of erotic and amorous encounters may induce passions-negative and positivethat overturn the maneuverings of love as tactic. Perhaps the headless mannequins suggest that the use of love as a reasoned tool of empire ignores the passions of the heart that result in losing one's head-losing one's reason, strategies and tactics-in favour of the Other one loves.

For Bhabha, colonial authority cannot control the effects of its discourses and strategies. Colonial rule attempts to induce the colonised to conform to its rationality, conventions and knowledges, but the resulting mimicry cannot replicate the original and instead reveals a difference. In this space of difference resistance emerges for, through the inexact mimicry, 'a form of subversion, founded on the undecidability ... turns the discursive conditions of dominance into the grounds of intervention'.21 Like other Western discourses, love as a strategy of colonialism cannot be controlled: the Western narrative of love is rearticulated and reproduced otherwise so that its outcome deviates from the original-creating, potentially, another love that may repudiate Empire in its embrace of the other.

\section{-Genealogical versus romantic intimacy}

While Matsuda reveals two strategies of love-concealment of colonial violence and creation of alliances with the colonised-Elizabeth Povinelli points to a third 
strategy within the colonial love-story. With a focus on the Australian situation, Povinelli suggests that in colonial and postcolonial contexts, Western love is differentiated from Indigenous genealogical bonds in such a way that the former is associated with valued terms including autonomy, freedom and humanism while the latter is deemed to be determined by custom and culture and without the possibility of individual freedom or even humanity. Western discourses of love, she argues, evolved in close proximity to liberal humanism-the subject-in-love like the sovereign-subject are founded on ideals of individuality and freedom. The Western subject-in-love does not enter a relation determined by familial or social requirements but chooses her affinities regardless of mores and traditions-or so the mythology goes. ${ }^{22}$ This Western ideal of love-based marriage and family relations developed throughout the eighteenth and nineteenth centuries as aristocratic social formations were replaced by bourgeois arrangements. However, as Habermas argues, this ideal of love was largely a fabrication as the preservation and inheritance of family wealth continued to be a major preoccupation. ${ }^{23}$ Even in the present, Habermas suggests, there continues to be a conflict between this myth of love and economic and social considerations in the formation of intimate relations.

This association of Western love with humanism and freedom is reinforced through its differentiation from genealogical intimacy. Genealogical relations are linked with inheritance, determinism and antiquity, and associated with the cultural Other and Indigeniety. Genealogical intimacy involves the creation of alliances based on traditional practices and kinship requirements and is founded on economic and reproductive imperatives rather than on ideals of love. This distinction creates, Povinelli writes: 'two kinds of worlds, starkly separated and morally opposed. One is autological; the other is genealogical.'24

Povinelli argues that this construction of an opposition between Western love and Indigenous genealogical connection was and is a central mechanism for distinguishing between Western and non-Western sociality. It thereby valorises the humanism and freedom of the West in opposition to the dehumanised determining traditions of Indigeneity. She questions this opposition, demonstrates the movement between the two constructions and contests the construal of the autological subject and modern intimacy as somehow disengaged from genealogical associations and 
conditions. ${ }^{25}$ More significantly, she delineates the ways genealogical intimacies are associated with a conception of a primitive past that requires the Indigenous subject to choose between the alternatives of Western love and genealogical intimacy, thus creating an inevitable failure either way. Choosing Western forms of the love relation necessitates the loss of culture and the ability to claim heritage including, in Australia for example, rights to land. Choosing genealogical-based relations on the other hand relegates the Indigenous subject to the realms of the past, the 'primitive', and even the inhuman. ${ }^{26}$

\section{- JARDIN D'AMOUR'S ICONS AND SYMBOLS}

Shonibare's installation puts in question this dichotomy between 'Western' autonomous romantic love and 'primitive' relations based on tradition, kinship requirements and economic imperatives. By using hybrid wax-print fabrics within European love scenes Shonibare questions the distinctions between individualised Western love and traditional genealogical love that Povinelli so clearly articulates. Shonibare's work contests the myth of individualised Western love unconstrained by the influences of family, economics and status, just as it problematises the relegation of non-Western love to an archaic dehumanised tradition. Love is denaturalised, revealing that games, rules, strategies, conventions and traditions govern the expression and experience of love in all cultures.

The insertion of wax-print fabric into European love scenes already disrupts the autonomous love / genealogical intimacy opposition, but the specific motifs and icons depicted on the fabrics Shonibare has choosen accentuate this effect. In his reinterpretation of 'The Lover Crowned', Shonibare clothes the female figure in a bustled gown adorned with the Chanel logo within large circles clearly differentiated from the rest of the patterning. The tambourine lying close by repeats the Chanel logo, now on a fabric of pinks and oranges that contrasts with the dress fabric in greens and browns. The male figure's jacket and breeches of orange, yellow and black depicts stylised Western cars and houses. These emblems of contemporary Western consumption and wealth bring the eighteenth-century clothing style and amorous encounters into the present. They also reintroduce Europe back into the 'African' fabrics, reinforcing the hybrid in-betweenness of culture. If 'African' waxprints are introduced into European love scenes, conversely, European icons have 
infiltrated the 'African' fabrics, bringing about an oscillation between cultures that reflects the condition of our times.

Through this entwinement Shonibare's work also complicates the distinction between Western autonomous love relations and non-Western relations based on kinship, heritage and tradition. Fragonard depicts aristocratic love scenes that reference the economic and familial basis for marriage while also gesturing to the extra-marital courtly traditions in which the knight illicitly woos his lady. Fragonard's works already reveal the protocols, traditions and economic motivations inherent in Western love. Shonibare extends this theme by introducing African, Indonesian, Dutch and hybrid cultures (all inherent in the wax-print fabrics) as well as Western bourgeois (as opposed to aristocratic) modernity implied by the Chanel icons, cars and houses. Modern bourgeois Western love is just as imbued with economic, status and kinship considerations as either Western aristocratic or non-Western Indigenous practices. The 'primitive' or Indigenous can no longer be distinguished from the 'civilised' as aristocratic love rituals are as entrenched as the 'primitive' in tradition. Games of love, Shonibare's installation suggests, are inherent in all cultures and ages and these games are as much about status, wealth and family as they are about desire, autonomous choice and freely chosen attachments.

Shonibare's work, however, is not simply a negative critique of love and its role in the construction of empire. It is also a ravishing portrayal of romance that reveals the pleasures of amorous play and the thrill of courtship and passion. In his reconstruction of Fragonard's The Pursuit there remains the sweetness of the lover's offer of a rose to his paramour; her coy leap away from his intrusion still conveys her ecstatic excitement and her flirtatious flight continues to beguile and entice. Indeed, the transformation from the rather mannered original achieved by the use of the brilliant wax-print fabrics reinvigorates these scenes and renews their vitality and enchantment.

Shonibare's work simultaneously gestures to the manipulative strategies of love deployed in the colonial conquest and also communicates the rapture of the amorous encounter. This other side to Shonibare's work, this representation of the pleasures and rewards of love, speaks to an alternative depiction of the role of love in the colonial encounter. Most theorists point to the manipulations and regulations 
surrounding colonial intimacy, but some have proposed that love can also inspire resistance to the degradation and subjectification enacted by colonial rule.

\section{-ANTI-COLONIAL LOVE}

In Methodology of the Oppressed, Chela Sandoval argues that love enables 'a differential mode of consciousness' that facilitates decolonisation. ${ }^{27}$ She writes: 'It is love that can access and guide our theoretical and political "movidas"revolutionary manoeuvres toward decolonized being'.28 Sandoval identifies a distinction between a normative 'narrative love' and a 'revolutionary love' or 'prophetic love' that ruptures prescriptive discourses and facilitates an alterconsciousness. $^{29}$ Sandoval describes this as a 'complex kind of love in the postmodern world, where love is understood as affinity-alliance and affection across lines of difference that intersect both in and out of the body'. ${ }^{30}$

From a different perspective Leela Gandhi also points to the anti-imperialism that may be encouraged by affective connections across cultures. Hoping to augment postcolonial scholarship by focusing on the anti-imperialism of Western subjects who have renounced the privileges of imperialism and elected affinity with the victims of their own expansionist cultures', Gandhi traces the intimate friendships across cultures that imperil colonial ambitions. ${ }^{31}$ She references E.M. Forster's manifesto from Two Cheers for Democracy-'If I had to choose between betraying my country and betraying my friend I hope I should have the guts to betray my country'-elaborates encounters between coloniser and colonised that perform cross-cultural collaborations as friendship and as love. ${ }^{32}$

Gandhi's larger project involves questioning various orthodoxies of postcolonial theory and progressive politics more generally. Challenging the critique of English literature as a tool of imperialism, Gandhi proposes that 'English literature as often as not fuelled the energies of anticolonialism in South Asia'. ${ }^{33}$ Elaborating this proposition she recounts the experience of Manmohan Ghose, the late Victorian Oxford-educated Hindu, who was welcomed into and celebrated within Oscar Wilde's circle. In his review of Ghose's poetry Wilde writes that his verses 'suggest how close is the bond of union that might one day bind India to us by other methods than those of commerce and military strength'. ${ }^{34}$ 
Gandhi advocates a utopian politics and reveals the associations between such politics and anti-colonial friendships. These affinities may be demonstrated through small gestures like that of the lone protester in the Australian desert who admonishes her government's incarceration of refugees, and, approaching the isolated Woomera detention centre, holds up a placard assuring the asylum seekers: 'You are not alone'. Though turned back by guards this woman's action repudiates her alliance with her country in favour of friendship with unknown refugees. For Gandhi, this lone protester is relinquishing the comforts of complicity with her own society and government in preference for a fleeting connection with strangers, more commonly seen as intruders who imperil the Australian nation. ${ }^{35}$ This may be understood, in sympathy with Emmanuel Levinas, Gandhi speculates, as a 'proximity to the other ... signifying "the surplus of sociality over solitude-the surplus of sociality and love"'. 36 Though a small act, this offer of friendship, sociality and love challenges the aggression inherent in the government's paranoid and parochial protection of its borders from those who seek shelter after fleeing the destruction of their own homes and communities.

Gandhi's other examples indicate more enduring bonds; among them the friendship between the English Anglican priest Charles Andrews and Indian antiimperialist activist Mahatma Gandhi is illustrative. In 1914, Andrews resigned from his post as vice-principal of St Stephen's College at Delhi University and travelled to South Africa to support Gandhi's advocacy for Indian indentured labourers. When met by Mahatma Gandhi on his arrival, Andrews bent and touched his feet, an act that reverses, Leela Gandhi proposes, the hierarchy of colonialism through 'a single, defiant gesture of self-abnegation'. ${ }^{37}$ The gesture attests to a disruptive politics of friendship that prioritises the friend over national allegiances.

These instances of friendship, alliance and affinity across the colonial divide challenge the prevailing orthodoxy that represents love as a tool of empire. These theorists suggest that love does not operate only as a technology of colonial conquest disguising violence, securing compliance and valorising Western models of love over indigenous genealogical bonds, but that it is also, potentially, a means to disrupt the ambitions of imperialism. While Matsuda and Povinelli identify the operation of the Empire of Love, Sandoval and Gandhi rupture a totalising story that 
simply negates love as a means of conquest. Instead they reveal the possibility of an anticolonial love, a disruptive love, that defies the Empire of Love.

How are we to understand the concept of love given these divergent experiences? Are these different and contradictory modes of love? Is one an illusory and deceptive love and the other a genuine emotion? Or are these both aspects of the experience and expression of love? If love may both advance the ambitions of empire and thwart or challenge the hegemony of colonialism, this suggests that love's operations are complex, multiple and divergent. What is this love that appears to at once consolidate and fracture colonial dominion?

\section{- JARDIN D'AMOUR'S LABYRINTHS}

Shonibare's three scenes of lovers are situated within a maze constructed of trellises and fake foliage. Viewers must enter the maze and follow its passages and pathways in order to stumble upon the scenes of courtship and seduction. If Fragonard's work may be equated with a garden, in so far as viewers may choose their own pathways and narratives around and between the four paintings, then Shonibare actualises this imagined wandering as the viewer enters the maze and becomes part of the work and so complicit with the romance and privilege it depicts. Moving within the foliage of the labyrinth, searching for each scene, the viewer also plays the game of love-of flight and conquest represented especially in 'The Pursuit', in which the beloved appears to be startled and flees with outstretched arms from her lover who is attempting to present her with a rose. The maze, like love, is not complete absence or complete presence. It is the passage, the movement, the quest, the delay. It is a space between that creates desire and defers its fulfilment. In this work the maze allows a movement between past and present, while it also precipitates the viewer into the space of love, colonialism, conquest, pleasure, extravagance, luxury, subjugation-all intertwined within the images, the references, the metaphors and the structure of the work.

The Musee du Quai Branly where Shonibare's work was first exhibited is itself a maze-like construction. When the visitor passes beneath the building where tickets are sold, they enter a darkened tunnel that gradually ascends into the upper level interiors, which are themselves labyrinthine. The spiralling tunnel evokes the voyages of discovery that enabled Europeans to 'collect' the artefacts from Asia, 
Africa and the Pacific that are displayed above. Creating a maze within a maze, Shonibare reverses the journeying from metropole to periphery, ensuring that the visitor encounters the intimate exploitations at the heart of the colonising empire. But this is no simple reversal for he also situates within the core of Empire the hybrid wax-print fabrics that reveal the dependence of Europe on its Other and at the same time reveals the entwinement of cultures that are always necessarily interlinked. Shonibare's work, situated within the ethnographic collections of the Quai Branly, questions the separation of the cultural Other and the metropolitan centre by putting the European culture on display but at the same time revealing its connections with the othered cultures (exhibited throughout the Musee) that support and define it.

The Jardin d'Amour maze also works to redefine love. Love is more commonly constructed as either enslavement or freedom, self-centered or self-sacrificing, but as a tool of Empire or a foundation for anti-colonialism, the maze of love suggests an alternative reading of love as a revealing and opening of self and other. By entering the maze the visitor/lover already intrudes into and exposes the other and through this experience is herself laid bare and transformed. Through the mechanism of the maze the visitor is inserted into or cuts into the scene of love. This is at once an act of violence and intrusion and at the same time a voyage or passage toward difference and an exposure to the challenge, to the subversions, presented by the work. Shonibare's work demands the viewer enter into the work, intrude or cut into the work and thereby become changed by the work. This process emulates the mechanisms of love in which each lover enters into the other, exposes each other, and is altered by the other through a caress that is also a violence is so far as it results in a necessary transformation of self and other.

\section{-ShATTERED LOVE}

The understanding of colonial love as a contradiction-as both a violent colonial assimilation and as a resistant recognition of alterity-conforms with a long tradition in which love is conceived as opposition: as both bitter and sweet, freedom and bondage, altruistic and egoistic, spiritual and carnal. Within this traditional conception these oppositions create a dialectical movement oscillating between these dichotomies until one is sublated within the other. The one is not destroyed 
but incorporated into the other in a movement that resolves and clarifies the characteristics of love. ${ }^{38}$ This conception of love mimics a broader construction of dialectical oppositions between the heart and the subject, love and reason, passion and thought.

Against this tradition, however, the French philosopher Jean-Luc Nancy proposes a thinking of love not as dialectic or as contradiction but as exposition. Rather than conceive love as constituted through opposition and through its sublation into a final resolved stability, Nancy proposes that love be understood as revealment or openness. This exposure, Nancy concedes, may be similar to or an aspect of the dialectic but it does not resolve into a closure; instead it continually effuses as an ongoing outpouring or divulging. Love, in this conception, is a ceaseless process that avoids stasis or stability by continually transforming the subject through its exposure, both as revealment and vulnerability, to the Other. ${ }^{39}$

For Nancy, love is the act that inaugurates the subject, the act that brings the subject into being. There is no subject before this moment of love. Moreover, love constitutes the subject as fractured: love opens the subject introducing alterity into the heart of the subject creating thereby a shattered subject. Nancy writes: 'he, this subject, was touched, broken into, in his subjectivity, and he is from then on, from the time of love, opened by this slice, broken and fractured, even if only slightly ... From then on, I is constituted broken'. 40

There is no autonomous autarchic subject for Nancy. Rather, subjectivity is constituted through interrelations, through sociality, through love and as a result we are shattered, multiple, disunified. Never simply an immanence closed in on itself, the self is always transported, opened and exposed by and with the other who touches, breaks, cuts the subject in love. Love, thus, is always a form of heart-break as love cutting open, exposes the one to the other so that: 'the immanence of the subject ... is opened up, broken into ... Love is the act of transcendence (of a transport, of a transgression, of a transparency ... ).'41

Nancy's exploration of love is an attempt to elaborate Heidegger's conception of Dasein (the human being) as a being-with-others. Heidegger proposes that concern (for things and others) is a fundamental structure or characteristic of Dasein but he fails to develop this concept of concern for the other. ${ }^{42}$ Nancy rectifies this lack, proposing that the subject (or, as he names it, the singularity) comes into existence 
within sociality or within love. This transforms Heidegger's individualistic Dasein into a human existence that is constituted through the effects of love and so through the effects of sociality. ${ }^{43}$ Against a tradition that envisages a pre-existing autonomic subject who subsequently experiences love, Nancy proposes that singularities only come into existence through love, within sociality, as a being-with-others.

It is tempting perhaps to separate the Empire of Love from anti-colonial love, dividing them into opposing modes or manifestations or instances of love. On the one hand, the Empire of Love could be aligned with conventional Western narratives of love in which love justifies acting for and on the Other despite the Other's desires. On the other hand, anti-colonial love might be conceived as an ethical love that recognises alterity, acknowledges difference and prioritises the Other's needs, culture and modes of being. Yet each of these modes of love continues to assume an a priori subject who subsequently loves and is loved. Moreover, each ignores the complexity of love for love is not ethical in one expression and violent in another. Rather, love is the inauguration of the subject as a hybridity who is therefore always to some degree othered, and so foreign to itself. Love is not ever simply a comfortable reassuring reaffirmation of the self and other, for love enters into the heart of being creating the subject or the singularity within sociality as an already multiple, othered being. This process of inauguration through love involves caress and violence, affection and passion.

Not only does Nancy's conception of love challenge the priority of the isolated, self-contained subject by revealing the pre-existence of love and sociality, but it also contests the dichotomising of violent love and ethical love. All love, for Nancy, involves a certain violation as all love intrudes upon and transforms the autonomous subject. A single act of love may, therefore, simultaneously exemplify the Empire of Love and anti-colonial disruptive love. The friendship of Reverend Andrews and Mahatma Gandhi may be such an instance insofar as Andrew's Christian love cannot but have the effect of extending Western imperial ambitions in India, yet his involvement with Gandhi simultaneously disrupts these ambitions. Similarly, Loti's love affair with the Asian or Pacific Other, exemplified in his sentimental romances that disguised and justified the French imperial project, also inspired the resistance to empire evident in his reportage of the massacre in the Red River delta. Andrews and Loti each, one may speculate, are cut open, exposed, 
transformed, and made foreign by their intimate and affectionate relations with the colonised Other thereby reconstituting each as, to a greater or lesser degree, other.

This is not to condone the forms of imperial love identified by Matsuda and Povinelli. Rather, conceiving love as transformation and hybridisation alerts us to the dangers as well as the pleasures inherent in every act of love. Imperial love is able to negate precisely because there is also the potential to create the pleasures of love. Anti-colonial love may wish to augment the lives of others but must also recognise its own risks of negation-deliberate or inadvertent, incalculable, unforeseeable, uncontrollable. Love's pleasures carry within them violence and disruption which may enable transformation and becoming and/or may ruin the possibility of difference and alterity. Every act of love, every act of cross-cultural engagement risks imperial violence while also expressing the passion, affection and solicitude that is becoming (with) other(s).

Elsewhere, Nancy also writes of cultural exchange and interrelation, contesting the idea of cultural purity and proposing that all cultures are from the outset combined with other cultures. Like the subject, who is inaugurated through the fracturing of love, all cultures are from the beginning an amalgam or composite. To avoid the static closure of the term mixture, Nancy writes 'In Praise of Melee'.44 Culture is a process of becoming enabled by the melee of heterogeneous intermingling of cultures within culture. Melee involves both love and combat, Aphrodite and Ares, provoking 'blows and embraces, assaults and truces, rivalry and desire, supplication and defiance, dialogue and dispute, fear and pity, and laughter as well'. 45 The subject, like culture, is fracturing, transforming and becoming through its encounter with the other/stranger that involves the melee of Ares and Aphrodite. Yinka Shonibare's work performs this melee of Ares and Aphrodite, reformulating European images and cultures to reveal the alterity already hidden and disguised within the European imaginary and identity.

\section{-JARDIN D'AMOUR'S MELEE}

Fragonard's series of paintings, together titled 'The Progress of Love', are lovingly broken into, fractured, and shattered by Shonibare's 'Garden of Love'. The intrusion of the African-Indonesian-Dutch-hybrid wax-print fabrics and the headless figures ruptures the original significances of the works, simultaneously revealing their 
subtext and creating new connotations and associations. The wax-print fabrics break into the heart of colonial empire fracturing and thereby reinvent, redefine and transform that identity. Additionally, Shonibare's engagement with Fragonard shatters the representation of love in the original eighteenth-century works. In the latter, love is depicted as a romantic encounter that happens to already constituted subjects. Shonibare's intervention demonstrates that these subjects are altered and reconstituted through loving interventions so that subjects are made and remade by love. Shonibare overturns the Western narrative about pre-existing beings making love by showing instead that we are made by love.

Shonibare's recreation touches Fragonard's work, lovingly reproducing the beauty, frivolity and pleasure of the work while also violently reinventing the meaning of the images and with that dual gesture mutating or metamorphosing the work. The ambiguous narrative structure in Fragonard's original is materialised as the labyrinth through which the viewer enters into the installation and pursues varying pathways that induce multiple interpretations and narratives. At the same time, through the same mechanism of the maze, the viewer becomes incorporated into this violently affectionate, affective transformation that Shonibare has enabled. Fragonard is cut open and exposed by Shonibare and the viewer, too, is confronted and disclosed. The identity of each is transformed as the reality of colonial heritage and privilege are brought home. In the heart and home of Empire the repressed and denied colonial project is announced and revealed.

This confrontation and disclosure challenges the autarchy of the culture and of the self, undermining the seeming autonomy of Europe and of the individual viewer. Each identity is created and recreated through the hybrid bringing together of Europe, Africa (and Indonesia and the Netherlands), artwork and viewer, love and violence, mannered courtship and flamboyant exuberance. The familiar and strange, the self and other, are neither opposed to each other nor fused into one but are instead brought into an encounter, entwinement and confrontation through which each reworks and redefines and recreates the other so that each is henceforth affected and altered. This melee of love that confronts and exposes the self to the other opens up new possibilities and new futures. The subject, henceforth no longer merely a self but already othered through this process, now adventures along alternative pathways and passages, creates different associations and connections, 
perceives new meanings and produces other worlds. 'Garden of Love' offers the possibility of adventuring with the other as well as the risk of losing or relinquishing the autarchy of self.

Linnell Secomb is the author of Philosophy and Love: From Plato to Popular Culture. Her interdisciplinary research focuses on emotion in narrative and culture. She has taught in Australian and UK universities and is currently a senior lecturer in Humanities and Social Sciences at the University of Greenwich.

\section{-NOTES}

${ }^{1}$ Marion Halligan, 'A Lovely Neck of the Woods', The Age, 25 August 2007; Richard Cork, 'In the Labyrinth', The Spectator, 12 May 2007; Ronald Jones, 'Yinka Shonibare: Musée du Quai Branly', Artforum, October 2007.

2 Mary D. Sherrif, Fragonard: Art and Eroticism, University of Chicago Press, Chicago, 1990, p. 58.

3 Ibid., p. 64.

4 Ibid., pp. 68, 73.

5 Ibid., pp. 73-82.

${ }^{6}$ Ibid., p. 94.

7 Robert Aldrich, Greater France: A History of French Overseas Expansion, Palgrave, Hampshire, 1996, pp. 10-23; Frederick Quinn, The French Overseas Empire, Praeger, Westport, 2001, pp. 39-106.

8 Robert Hobbs, 'Yinka Shonibare MBE: The Politics of Representation' in Yinka Shonibare MBE, Catalogue for exhibition at Museum of Contemporary Art, Sydney, Prestel Verlag, Munich, 2008, pp. 2830; Sandra Klopper, 'Redressing the Past: The Africanisation of Sartorial Style in Contemporary South Africa' in Hybridity and Its Discontents: Politics, Science, Culture, eds Avatar Brah and Annie Coombes, Routledge, London, 2000, pp. 216-31.

9 Janice Cheddie, 'A Note: Yinka Shonibare: Dress Tells the Woman's Story', Fashion Theory, vol. 4, no. 3, 2000, 350-1.

10 Maria Wroñska-Friend, 'Javanese Batik: The Art of Wax and Design', Batik: 75 Selected Masterpieces, eds Isa Fleischmann-Heck, et al., Galeries Smend, Köln, 2006, p. 46.

${ }^{11}$ Homi Bhabha, 'Culture's in Between' in Multicultural States: Rethinking Difference and Identity, ed. David Bennett, Routledge, London and New York, 1998, pp. 29-36.

12 Homi Bhabha, The Location of Culture, Routledge, London and New York, 2000, p. 91.

13 Rachel Kent, 'Time and Transformation in the Art of Yinka Shonibare MBE', Yinka Shonibare MBE, Catalogue for exhibition at Museum of Contemporary Art, Sydney, Prestel Verlag, Munich, 2008, p. 15. 
14 Yinka Shonibare and Bernard Muller, 'Interview with Yinka Shonibare MBE', Yinka Shonibare, MBE: Jardin d'amour, Catalogue for exhibition at Musee du Quai Branly, Flammarion, Paris, 2007, p. 17. 15 qtd in Matt K. Matsuda, Empire of Love: Histories of France and the Pacific, Oxford University Press, Oxford, 2002, p. 4.

16 Matsuda, p. 8.

17 Ibid., p. 19.

${ }^{18} \mathrm{qtd}$ in Matsuda, p. 33.

${ }^{19}$ Matsuda, p. 123.

20 Ibid., p. 124.

${ }^{21}$ Bhabha, The Location of Culture, p. 112.

22 Elizabeth A. Povinelli, The Empire of Love: Toward a Theory of Intimacy, Genealogy, and Carnality, Duke University Press, Durham, 2006, pp. 188-9.

23 Jürgen Habermas, The Structural Transformation of the Public Sphere, Polity, Cambridge, 2011, p. 47.

24 Povinelli, The Empire of Love, p. 208.

25 Ibid., p. 215.

26 Ibid., pp. 227-8.

27 C. Sandoval, Methodology of the Oppressed, University of Minnesota Press, Minneapolis, 2000, p. 139.

28 Ibid., p. 140.

${ }^{29}$ Ibid., p. 141.

30 Ibid., p. 169.

${ }^{31}$ Leela Gandhi, Affective Communities: Anticolonial Thought, Fin-de-Siècle Radicalism, and the Politics of Friendship, Duke University Press, Durham, 2006, p. 1.

32 Forster qtd in Gandhi, p. 10.

33 Ibid., p. 12.

${ }^{34}$ qtd in Gandhi, p. 143.

35 Gandhi, p. 16.

36 Ibid.

37 Ibid., p. 14.

38 Jean-Luc Nancy, 'Shattered Love', A Finite Thinking, Stanford University Press, Stanford, p. 251.

39 Ibid., p. 253.

40 Ibid., p. 261.

41 Ibid., p. 261.

42 Ibid., p. 208.

43 Ibid., pp. 267-9.

${ }^{44}$ Jean-Luc Nancy, 'In Praise of Melee', A Finite Thinking, Stanford University Press, Stanford,

45 Ibid., p. 287. 